\title{
Evaluation of QIAamp DNA mini kit for removing of inhibitors in detection of Cryptosporidium parvum oocysts in water samples by a nested- PCR assay
}

\author{
${ }^{1 *}$ M. Nikaeen, ${ }^{2}$ K. Makimura \\ ${ }^{1}$ Department of Environmental Health Engineering, School of Public Health, \\ Isfahan University of Medical Sciences, Isfahan, Iran \\ ${ }^{2}$ Department of Molecular Biology and Gene Diagnosis, Teikyo University, Tokyo, Japan
}

Received 29 November 2006; revised 26 February 2007; accepted 5 March 2007; available online 20 March 2007

\begin{abstract}
In recent years, there has been a dramatic increase in the occurrence of waterborne disease outbreaks caused by the Cryptosporidium parvum, and presence of this protozoan parasite in drinking water is a significant health problem faced by the water industry. A new strategy for detection of Cryptosporidium oocysts in water samples is PCR- based techniques. In this study a nested- PCR assay was designed for the specific amplification of a 199 bp DNA fragment of the gene encoding the heat shock protein (hsp70) of Cryptosporidium parvum oocysts. In order to prevent the inhibition of PCR amplification by substances contained in water samples, three DNA purification methods including QIAamp DNA mini kit, InstaGene Matrix, MagExtractor - Genome were compared in concentrates of tap water samples spiked with the oocysts. After it was found that the QIAamp is only efficient purification technique, the efficiency of QIAamp and immunomagnetic separation for nested-PCR assay of various water samples was compared. The results show that QIAamp provide a useful and rapid tool for removing of PCR inhibitors. It seems that QIAamp purificationnested PCR assay is a sensitive, rapid and cost effective method for detection of Cryptosporidium parvum oocysts in clean water samples with turbidity $<2$ nephelometric turbidity unit (NTU).
\end{abstract}

Key words: Cryptosporidium, PCR, detection, QIAamp, water, purification

\section{INTRODUCTION}

The protozoan parasite Cryptosporidium parvum has recently been recognized as an important cause of waterborne gastrointestinal disease worldwide (Fayer, et al., 2000; Sturbaum, et al., 2002). The organism can cause self-limited diarrhea in immunocompetent hosts and chronic, life threatening diarrhea in immunocompromised individuals, such as patients receiving immunosuppressive therapy and those suffered from acquired immunodeficiency syndrome (AIDS) (Fayer and Ungar, 1986).

The widespread occurrence of Cryptosporidium oocysts in surface waters (LeChevallier and Norton, 1995; LeChevallier, et al., 1991; Lisle and Rose, 1995), the low dosage required for infection (Dupont, et al., 1995) and their resistance to the normal chlorine disinfection level used in water treatment plants (Korich, et al., 1990) has become a major concern for water industry and increased the need for

\footnotetext{
*Corresponding author, Email: nikaeen_m@yahoo.com

Tel.: +98 3117922 660; Fax:+98 3116682509
}

understanding occurrence and distribution of the parasite in drinking and environmental waters. Therefore effective monitoring methods required for detection of Cryptosporidium oocysts in water samples. The immunofluorescence assay (IFA) which is widely used for detection of Cryptosporidium oocysts in water samples has many limitations (LeChevallier, et al., 2003). Considerable effort is being made worldwide to improve detection methodologies through the application of techniques such as flow cytometry (Vesey, et al., 1994) ELISA (De La Cruz and Sivaganesan, 1994) and PCR (Johnson, et al., 1995; Kozwich, et al., 2000; Mayer and Palmer, 1996; Rochelle, et al., 1997a). PCR in particular is a rapid, sensitive and pathogen specific (Kauncer and Stinear, 1998; Rochelle, et al., 1997a) procedure that can overcome the limitations of other methods. PCR amplification enabled detection of one Cryptosporidium oocyst in purified samples, but the method faces some limitations in testing of water samples due to presence of PCR 
inhibitors such as humic acids (Johnson, et al., 1995; Lowery, et al., 2000; Rochelle, et al., 1997a). Attempts have been made to overcome this problem by purification of extracted nucleic acids by spin column (Rochelle, et al., 1997b), addition of compounds to amplification reaction mixtures to overcome inhibition (Rochelle, et al., 1997a), hybridization to specific probes (Awad-el-Kariem, et al., 1994; Carraway, et al., 1996) and immunomagnetic separation (IMS) of target microbial pathogens before DNA extraction (Deng, et al., 1997; Griffin and Rose, 1995; Hallier-Soulier and Guillot, 1999). In the present study firstly we evaluate efficiency of three DNA purification methods including QIAamp DNA mini kit, Instagene Matrix and MagExtractor Genome for detection of Cryptosporidium parvum oocysts spiked in packed pellet concentrates of tap water by a nested-PCR assay. We compared IMS- nested PCR and QIAamp-nested PCR for detection of low numbers of C.Parvum oocysts seeded in various concentrated water samples.

\section{MATERIALS AND METHODS}

C.Parvum oocysts stock: Cryptosporidium parvum oocysts were obtained as purified and enumerated form from National Institute of Infectious Diseases (NIID, Tokyo, Japan). Different oocyst densities were prepared by dilution in sterile deionized water. Nested-PCR sensitivity evaluation: sensitivity of nested-PCR was tested with different numbers of purified C. Parvum oocysts. Spiking of test water samples: in order to evaluate the performance of the purification methods, packed pellets of tap water samples (50 L) spiked with 100 Cryptosporidium oocysts in triplicate for each method. Packed pellets of water samples were obtained by filtering of water through a $142 \mathrm{~mm}$ diameter cellulose nitrate membrane filter (Millipore) with a pore size of $1.2 \mu \mathrm{m}$. After filtration, the membrane was carefully rinsed with phosphate buffered saline (PBS) containing $0.02 \%$ sodium dodecyle sulfate (SDS) and tween 80 and centrifuged for $15 \mathrm{~min}$ at $3000 \mathrm{rpm}$ to produce packed pellet. Extraction of nucleic acid: DNA was extracted from purified oocysts by eight cycles of freezing in liquid nitrogen for $1 \mathrm{~min}$, followed by thawing at $98^{\circ} \mathrm{C}$ for $1 \mathrm{~min}$.

DNA extraction and purification of spiked concentrates:

Instagen Matrix (Bio-Rad): DNA was released in the presence of Instagen Matrix by eight cycles of freezing and thawing. DNA was then removed by centrifugation for 3 min at $12000 \mathrm{rpm}$ and used directly in PCR reaction.

MagExtractor - Genome (Toyobo): according to the manufacturer's protocol $750 \mu \mathrm{L}$ lysis buffer and $40 \mu \mathrm{L}$ of magnetic beads were added to pellets containing oocysts. After eight cycles of freeze and thaw, DNA purification was performed as outlined by the manufacture.

QIAamp DNA min kit (QIAgen K.K., Japan): DNA was extracted and purified from spiked concentrates of water samples by using a QIAamp DNA min kit according to the manufacturer's instruction with some modifications including eight cycles of freeze and thaw after incubation at $56^{\circ} \mathrm{C}$ and rapid centrifugation before purification of DNA by spin columns.

PCR: A nested-PCR was performed to detect Cryptosporidium oocysts. PCR primers (CPHSP2) which amplified a 361 bp fragment of $C$. parvum heat shock protein gene (hsp70) were reported previously by Rochelle, et al. (1997b). Nested primers NesCPHF (5 $\mu$ - TGGTGGTGTTATGACCAAGC) and NesCPHR (5 $\mu$-TGGTACACCTCTTGGTGCT G) which amplified a 199 bp product within the first amplicon were designed using DNASIS software (Hitachi software, Japan). The reaction was carried out on a PCR thermal cycler (Takara, Japan) in $200 \mu \mathrm{L}$ PCR tubes containing $30 \mu \mathrm{L}$ of reaction mixture and $20 \mu \mathrm{L}$ of template. The primary PCR contained $100 \mu \mathrm{M}$ dNTP, $300 \mathrm{nM}$ each forward and reverse CPHSP2 primers, $2.5 \mu$ Lof bovine serum albumin (10 mg/mL, sigma), $1 \times$ PCR buffer, 1.25 unit of taq polymerase. The nested PCR amplified $1 \mu \mathrm{L}$ of the primary PCR product. The secondary PCR components were the same as the primary PCR with the exception of nested primers and concentration of dNTP $(20 \mu \mathrm{M})$. Bovine serum albumin also was not included in the reaction mixture.

The following thermal protocol was used: primary PCR consisted of an initial denaturation at $95^{\circ} \mathrm{C}$ for 5 min; 35 cycles of $94^{\circ} \mathrm{C}$ for $1 \mathrm{~min}, 55^{\circ} \mathrm{C}$ for $2 \mathrm{~min}$ and 72 ${ }^{\circ} \mathrm{C}$ for $1 \mathrm{~min}$ and final extension at $72^{\circ} \mathrm{C}$ for $10 \mathrm{~min}$. The nested PCR amplification parameters were $5 \mathrm{~min}$ at 94 ${ }^{\circ} \mathrm{C}, 30 \mathrm{~s}$ at $94^{\circ} \mathrm{C}, 45 \mathrm{~s}$ at $58^{\circ} \mathrm{C}$, and $30 \mathrm{~s}$ at $72^{\circ} \mathrm{C}$ for 30 cycles; and finally $10 \mathrm{~min}$ at $72^{\circ} \mathrm{C}$.

Positive and negative controls were run with every PCR set. Detection of amplified PCR products: The PCR product was analyzed by electrophoresis in a $1.6 \%$ ogarose gel and was visualized with a image master VDS system (Pharmacia, Biotech) after staining with etidium bromide $(0.5 \mu \mathrm{g} / \mathrm{mL})$. 
Comparison between QIAamp-nested PCR and IMS-nested PCR: replicate tubes containing different water sample concentrates which spiked with C.Parvum oocysts were processed by both QIAampnested PCR and immunomagnetic separation (IMS)nested PCR. The turbidity of water samples was determined with a spectrophotometer (BEKMAN DU 650). Immunomagnetic separation: spiked concentrates of water samples were subjected to IMS as outlined by manufacture and then purified oocycts subjected to the DNA extraction by eight cycles of freeze and thaw. Negative control in which oocyst or DNA was replaced with sterile distilled water were included in the spiking step and in the PCR amplification.

\section{RESULTS}

Nested - PCR assay sensitivity: to determine the sensitivity of newly designed nested-PCR primer set described in this study, dilution of C. Parvum oocysts were prepared and nested-PCR was performed. Fig. 1 a shows that with CPHSP primers, oocyst dilutions were detected at a level of approximately $10^{2}$ oocysts, but using nested -PCR it can detect as few as one oocyst (Fig. 1b). Efficiency of purification methods: nested-PCR amplification of the DNA purified by QIAamp from the tap water concentrates seeded with $10^{2}$ Cryptosporidium oocysts generated a 199 bp DNA fragment. However when other DNA purification methods were used with the tap water concentrates, which were seeded similarly with Cryptosporidium oocysts, the target gene failed to amplify.

These results suggest that other DNA purification procedures except QIAamp may not yield enough pure
DNA to support PCR amplification for detection of Cryptosporidium oocysts in tap water.

Limit of detection of QIAamp-nested PCR: To demonstrate the sensitivity of the method, the limit of the detection when QIAamp used as DNA purification procedure was determined by spiking of tap water concentrates with 10, 5 and 1 oocyst. Fig. 2 shows that nested-PCR could amplify as few as one oocyst spiked in packed pellet concentrates of 50 liters tap water. Comparison of IMS-nested PCR and QIAamp-nested PCR: A comparative study between the IMS-nested PCR assay and QIAamp-nested PCR was carried out on spiked concentrates of treated and untreated water samples. The results are summarized in table 1 . These results show that our extraction purification method is compatible with low turbidity environmental water samples and the discrepancy between the two methods is related to environmental water samples with turbidities higher than 2 NTU.

\section{DISCUSSION AND CONCLUSION}

A common problem in PCR amplification of DNA extracted from environmental samples is inhibition by humic type materials that co-extract with DNA (Kozwich, et al., 2000; Mahbubani, et al., 1998). Techniques used specifically to relieve the inhibition and enhance PCR detection of Cryptosporidium oocysts include flow cytometry and immunomagnetic separation of oocysts from water samples prior to PCR (Johnson et al., 1995), and spin column purification of extracted DNA (Rochelle, et al., 1997b).
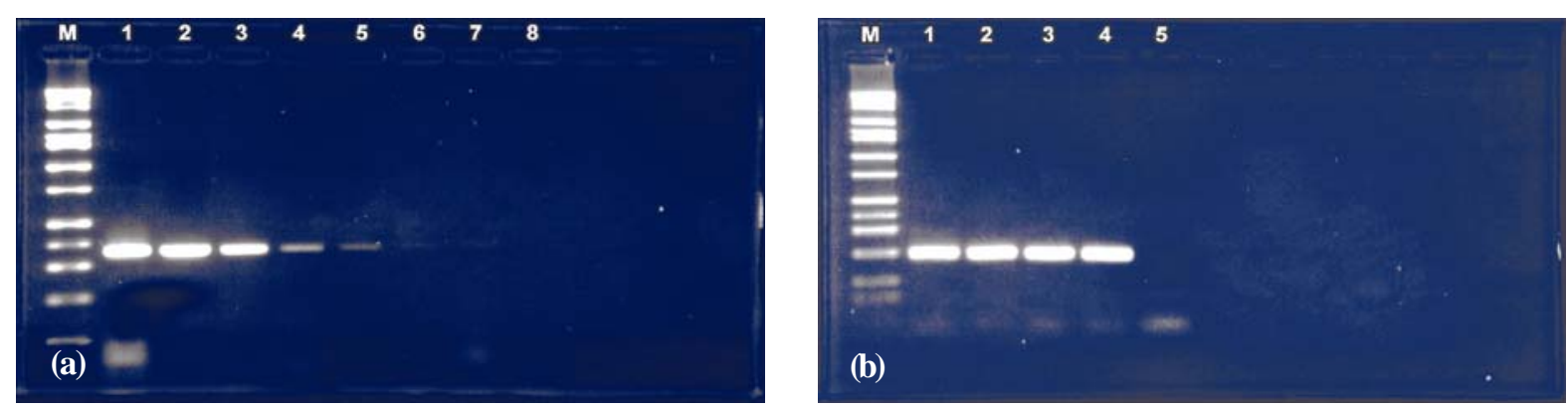

Fig. 1a: Sensitivity of the PCR assay for detection of $C$. parvum oocysts as determined by agarose gel electrophoresis. M: 100 bp ladder, Lane 1: positive control, Lane 2: $10^{4}$ oocysts, Lane 3: $10^{3}$ oocysts, Lane 4: $10^{2}$ oocysts, Lane 5: 10 oocysts, Lane 6: 5 oocysts, Lane 7: 1 oocyst, Lane 8: negative control. b: Sensitivity of the nested- PCR assay. Lane 1: positive control, Lane 2: 10 oocysts, Lane 3: 5 oocysts, Lane 4: 1 oocyst, Lane 5: negative control. 
Evaluation of QIAamp DNA mini kit for removing of inhibitors in detection of ...

Table 1: Comparison of results obtained by QIAamp-nested PCR and IMS-nested PCR for detection of C. Parvum oocysts in various water samples

\begin{tabular}{|c|c|c|c|c|c|c|}
\hline \multirow{2}{*}{ Sample } & \multirow{2}{*}{ Turbidity } & \multirow{2}{*}{ Volume Analyzed } & \multirow{2}{*}{ No. of seeded oocysts } & \multirow{2}{*}{ Replicate } & \multicolumn{2}{|c|}{ nested PCR detection } \\
\hline & & & & & QIA amp & IMS \\
\hline \multirow[t]{4}{*}{ *Tap water } & $<1$ & $10-60 \mathrm{~L}$ & 0 & 6 & - & $* *$ \\
\hline & & " & 1 & 6 & + & $* *$ \\
\hline & & $"$ & 10 & 6 & + & + \\
\hline & & $"$ & 100 & 3 & + & $* *$ \\
\hline River water & 1.5 & 20 & 0 & 1 & - & - \\
\hline River water & & & 5 & & - & - \\
\hline \multirow[t]{2}{*}{ River water } & 2.5 & 20 & 0 & 1 & - & - \\
\hline & & & 5 & & - & - \\
\hline \multirow[t]{2}{*}{ River water } & 3.5 & 30 & 0 & 1 & - & - \\
\hline & & & 5 & & - & + \\
\hline River water & & & 5 & & + & + \\
\hline \multirow[t]{3}{*}{ Stream water } & 1.9 & 15 & 0 & 1 & - & $* *$ \\
\hline & & & 5 & & + & $* *$ \\
\hline & & & 10 & & + & $* *$ \\
\hline
\end{tabular}

*For IMS one replicate, **IMS not performed

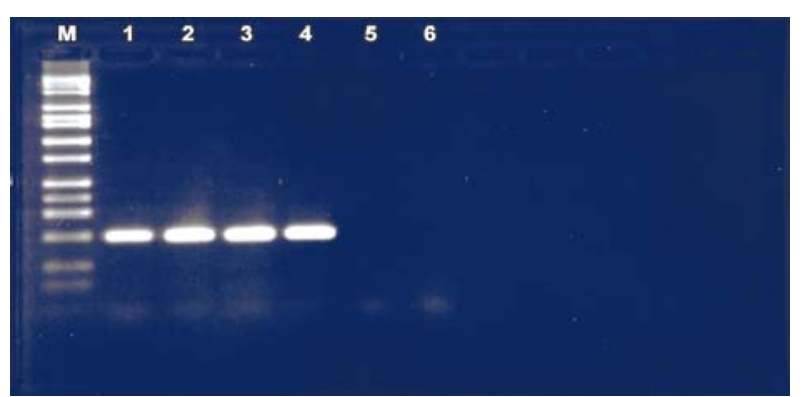

Fig. 2: Sensitivity of nested-PCR assay for detection of C. parvum oocysts spiked into packed pellet concentrates from 50 liters tap water samples after purification of DNA by QIAamp. M: 100 bp ladder, Lane 1: positive control, Lane 2: 10 oocysts, Lane 3: 5 oocysts, Lane 4: 1 oocyst, Lane 5: negative control without oocyst, Lane 6: negative control without DNA

Magnetic beads with attached oligonucleotides also have been used to isolate specific target nucleic acid (Kauncer and Stinear, 1998; Stinear, et al., 1996). In this study we used a nested-PCR assay which further enhances the sensitivity of PCR for detection of $C$. Parvum oocysts. Nested PCR has been used with various degrees of success to increase the sensitivity of detection, particularly for genes with one or a small number of copies (Inglis and Kalischuk, 2003). The nested-PCR method also was able to detect low numbers of $C$. parvum oocysts spiked into tap water concentrates. QIAamp DNA mini kit overcame potential nested-PCR inhibition and proved to be an efficient DNA purification procedure for tap water samples.
Although immunomagnetic separation (IMS) is now more commonly used and many researches have been used the method along with PCR for detection of Cryptosporidium oocysts in environmental samples (Hallier-Soulier and Guillot, 1996; Hallier-Soulier and Guillot, 2000; Rimhanen-finne, et al., 2001; Sturbaum, et al., 2002; Xiao, et al., 2001), but the procedure selectively separate the Cryptosporidium oocysts. However it would be advantageous to perform parallel detection assay for multiple pathogen on a single sample. This can be accomplished by extraction of total DNA from a concentrated water sample without selective separation (Rochelle, et al., 1997b). QIAamp has the advantage that will not selectively target the 
DNA of any one organism and therefore potentially could be used for purification of DNA in detection of organisms in water samples by PCR.

As indicated by the results of this study, there is a discrepancy between the two methods. The discrepancy was due to the samples with turbidities higher than 2 NTU. Samples of this nature may be expected to contain higher level of debris and PCR inhibitors that might bind DNA immediately upon release from the target microbial cells. Moreover nested-PCR amplification of the two samples failed when IMS was used. The higher level of algae in these samples, take as a guide to the level of humic acid, may explain the failure. Lowery et al. (2000) indicated that the sensitivity of IMS- PCR for environmental water samples with turbidity between 2.5 and $5 \%$ ppv. is 100 fold lower than water samples with turbidity below $2.5 \%$ ppv.

In conclusion QIAamp DNA mini kit is a suitable procedure for purification of DNA in water samples with low turbidity ( $<2$ NTU) especially tap water samples. The advantages of the method include reducing process time, expense and using the method for detection of any kind of microorganism by PCR based methods.

\section{ACKNOWLEDGEMENT}

The authors thank NIID for providing the oocysts stock and Mrs. Yuko Takahashi for technical assistance.

\section{REFERENCES}

Awad-el-Kariem, F.M., Warhurst, D.C., McDonald, V., (1994). Detection and species identification of Cryptosporidium oocysts using a system based on PCR and endonuclease restriction. Parasitology. 109, 19-22.

Carraway, M., Tzipori, S., Widmer, G., (1996). Identification of genetic heterogeneity in the Cryptosporidium parvum ribosomal repeat. Appl. Environ. Microbiol., 62, 712-716.

De La Cruz, A.A., Sivaganesan, M., (1994). Detection of Giardia and Cryptosporidium spp. in source water samples by commercial enzyme-immunoassay kits. Proc. AWWA Water Qual. Technol. Conf.

Deng, M.Q., Cliver, D.O., Mariam, T.W., (1997). Immunomagnetic capture PCR to detect viable Cryptosporidium parvum oocysts from environmental samples. Appl. Environ. Microbiol. 63 (8), 3134-3138.

Dupont, H.L., Chappell, C.L., Sterling, C.R., Okhuysen, P.C. Rose, J.B., Jakubowski, W., (1995). The infectivity of Cryptosporidium parvum in healthy volunteers. New Engl. J. Med., 332, 855-859.

Fayer, R., Ungar B.L.P., (1986). Cryptosporidium spp. and cryptosporidiosis. Microbiol. Rev., 50, 458-483.

Fayer, R., Morgan, U., Upton, S.J., (2000). Epidemiology of Cryptosporidium: transmission, detection and identification. Int. J. Parasitol., 30, 1305-1322.
Griffin, D.W., Rose J.B., (1995). The use of magnetic affinity cell sorting to enhance PCR detection of Cryptosporidium oocysts in environmental samples. Proc. AWWA Water Qual. Technol. Conf., 2231-2241.

Hallier-Soulier, S., Guillot, E., (1999). An immunomagnetic separation polymerase chain reaction assay for rapid and ultra-sensitive detection of Cryptosporidium parvum in drinking water. FEMS Microbiol. Lett., 176 (2), 285-289.

Hallier-Soulier, S., Guillot, E., (2000). Detection of cryptosporidia and Cryptosporidium parvum oocysts in environmental water samples by immunomagnetic separation-polymerase chain reaction. J. Appl. Microbiol., 89 (1), 5-10.

Inglis, G.D., Kalischuk, L.D., (2003). Use of PCR for direct detection of Campylobacter species in bovine feces. Appl. Environ. Microbiol., 69 (6), 3435-33447.

Johnson, D.W., Pieniazek, N.J., Griffin, D.W., Misener, L., Rose, J.B., (1995). Development of a PCR protocol for sensitive detection of Cryptosporidium oocysts in water samples. Appl. Environ. Microbiol., 61, 3849-3855.

Kaucner, C., Stinear, T., (1998). Sensitive and rapid detection of viable Giardia cysts and Cryptosporidium parvum oocysts in large-volume water samples with wound fiberglass cartridge filters and reverse transcription-PCR. Appl. Environ. Microbiol., 64 (5), 1743-1749.

Korich, D.G., Mead, J.R., Madore, M.S., Sinclair, N.A., Sterling, C.R., (1990). Effects of ozone, chlorine dioxide, chlorine, and monochloramine on Cryptosporidium parvum oocyst viability. Appl. Environ. Microbiol., 56, 1423-1428.

Kozwich, D., Johansen, K.A., Landau, K., Roehl, C.A., Woronoff, S., Roehl, P.A., (2000). Development of a novel, rapid integrated Cryptosporidium parvum detection assay. Appl. Environ. Microbiol., 66 (7), 2711-2717 .

LeChevallier, M.W., Di Giovanni, G.D., Clancy, J.L., Bukhari, Z., Bukhari, S., Rosen, J.S., Sobrinho, J., Frey, M.M., (2003). Comparison of Method 1623 and Cell Culture-PCR for Detection of Cryptosporidium spp. in Source Waters. Appl. Envir. Microbiol., 69, 971-979

LeChevallier, M.W., Norton, W.D., (1995). Giardia and Cryptosporidium in raw and finished water. J. AWWA, 87(9), 54-68.

LeChevallier, M.W., Norton, W.D., Lee, R.G., (1991). Occurrence of Giardia and Cryptosporidium spp. in surface water supplies. Appl. Environ. Microbiol., 57, 2610-2616.

Lisle, J.T., Rose, J.B., (1995). Cryptosporidium contamination of water in the USA and UK: a mini-review. J. Water SRT Aqua, 44 (3), 103-117.

Lowery, C.J., Moore, J.E., Millar, B.C., Burke, D.P., McCorry, K.A., Crothers, E., Dooley, J.S., (2000). Detection and speciation of Cryptosporidium spp. in environmental water samples by immunomagnetic separation, PCR and endonuclease restriction. J. Med. Microbiol., 49 (9), 779785.

Mahbubani, M.H., Schaefer, F.W., Jones, D.D., Bej, A.K., (1998). Detection of Giardia in environmental waters by immuno-PCR amplification methods. Curr. Microbiol. 36(2), 107-113.

Mayer, C.L., Palmer, C.J., (1996). Evaluation of PCR, nested PCR, and fluorescent antibodies for detection of Giardia and Cryptosporidium species in wastewater. Appl. Envir. Microbiol., 62 (6), 2081-2085 
Rimhanen-Finne, R., Ronkainen, P., Hanninen, M.L., (2001). Simultaneous detection of Cryptosporidium parvum and Giardia in sewage sludge by IC-PCR. J. Appl. Microbiol., 91 (6), 1030-1035.

Rochelle, P.A., De Leon, R., Stewart, M.H., Wolfe, R.L. (1997a). Comparison of primers and optimization of PCR conditions for detection of Cryptosporidium parvum and Giardia lamblia in water. Appl. Environ. Microbiol., 63(1), 106-111.

Rochelle, P.A., Ferguson, D.M., Handojo, T.J., De Leon, R., Stewart, M.H. and Wolfe, R.L., (1997b). An assay combining cell culture with reverse transcriptase PCR to detect and determine the infectivity of waterborne Cryptosporidium parvum. Appl. Environ. Microbiol., 63 (5), 2029-2037

Stinear, T., Matusan, A., Hines, K., Sandery, M., (1996). Detection of a single viable Cryptosporidium parvum oocyst in environmental water concentrates by reverse
transcription-PCR. Appl. Environ. Microbiol., 62 (9), 33853390

Sturbaum, G.D., Klonicki, P.T., Marshall, M.M., Jost, B.H., Clay, B.L., Sterling, C.R., (2002). Immunomagnetic separation (IMS)-fluorescent antibody detection and IMS PCR detection of seeded Cryptosporidium parvum oocysts in natural waters and their limitations. Appl. Environ. Microbiol., 68 (6), 29912996.

Vesey, G., Hutton, P., Champion, A., Ashbolt, N., Williams, K.L., Warton, A., Veal, D., (1994). Application of flow cytometric methods for the routine detection of Cryptosporidium and Giardia in water. Cytometry. 16 (1), 16.

Xiao, L., Singh, A., Limor, J., Graczyk, T.K., Gradus, S., Lal, A., (2001). Molecular characterization of Cryptosporidium oocysts in samples of raw surface water and wastewaters. Appl. Envir. Microbiol., 67 (3), 1097-1101.

\section{AUTHOR (S) BIOSKETCHES}

Nikaeen, M., Ph.D., Assistant Professor in the Department of Environmental Health Engineering, School of Public Health, Isfahan University of Medical Sciences, Isfahan, Iran. Email: nikaeen_m@yahoo.com

Makimura, K., M.D., Ph.D., Professor in the Department of Molecular Biology and Gene Diagnosis, Teikyo University, Tokyo, Japan. Email: makimura@main.teikyo-u.ac.jp

\section{This article should be referenced as follows:}

Nikaeen, M., Makimura, K., (2007). Evaluation of QIAamp DNA mini kit for removing of inhibitors in detection of Cryptosporidium parvum Oocysts in water samples by a nested-PCR assay. Int. J. Environ. Sci. Tech., 4 (2), 241-246. 